\title{
Meta-analysis of the efficacy and safety of Ginkgo biloba extract for the treatment of dementia
}

\author{
Masayuki Hashiguchi', Yuriko Ohta', Mikiko Shimizu², Junya Maruyama and Mayumi Mochizuki ${ }^{1 *}$
}

\begin{abstract}
Background: The benefit of Ginkgo biloba for the treatment of dementia remains controversial. The aim of this study was to evaluate the efficacy and safety of Ginkgo biloba in patients with dementia in whom administration effects were reported using meta-analysis.

Methods: We searched MEDLINE, Embase, the Cochrane databases, and Ichushi for controlled trials of Ginkgo biloba for the treatment dementia. Clinical characteristics and outcomes were extracted. Meta-analysis results were expressed as standard mean differences (SMDs) in scores of the Syndrome Kurztest (SKT), Alzheimer's Disease Assessment Scale Cognitive Subscale (ADAS-Cog) for cognition efficacy, or odds ratios (ORs) for dropouts and adverse drug reactions.

Results: Thirteen studies using the extract EGb761 met our inclusion criteria, which were duration of 12 to 52 weeks and daily dose of more than $120 \mathrm{mg}$, and included a total of 2381 patients. Meta-analysis was performed by using 9 of 13 studies, 7 of which used the SKT and 2 ADAS-Cog (dose 120 mg, 26 weeks) scores as efficacy parameters. In meta-analysis of all patients, SMDs (95\% confidence interval [CI]) in the change in SKT scores (7 studies) were in favor of Ginkgo biloba over placebo (SMD $=-0.90[-1.46,-0.34])$, but 2 studies that used ADAS-Cog did not show a statistically significant difference from placebo for ADAS-Cog $(-0.06[-0.41,0.30])$. For Alzheimer's disease (AD) and vascular dementia (VaD) subgroups, SMDs [95\% Cl] in SKT in the combined AD and VaD subgroup $(-1.07[-1.66,-0.47])$ and AD subgroup $(-1.36[-2.27,-0.46])$ were in favor of Ginkgo biloba over placebo. In terms of daily dose of Ginkgo biloba in the combined AD and VaD subgroup, SMD in SKT score in 240-mg daily dose groups was significantly greater than with placebo $(-0.71[-1.28,-0.14])$. Dropout rates for any reason did not differ between two groups, but dropout rates due to side effects were significantly lower in Ginkgo biloba groups compared with placebo groups ( $\mathrm{OR}=1.72[1.06,2.80])$.
\end{abstract}

Conclusions: Taking a 240-mg daily dose of Ginkgo biloba extract is effective and safe in the treatment of dementia.

Keywords: Meta-analysis, Ginkgo biloba extract, Dementia, Efficacy, Safety

\section{Background}

The standardized Ginkgo biloba extract EGb761 (Anatomical Therapeutic Chemical [ATC] code N06DX02) is classified as a therapeutic agent for dementia along with cholinesterase inhibitors and memantine in the ATC classification. Commission E of Germany [1], a committee that evaluates the efficacy and safety of herbal preparations, recognizes EGb761 as a medicine. The criteria for recognition as a medicine are improvement of symptoms, such as disturbance of memory, lack of concentration, depression, dizziness, tinnitus, etc., due to degenerative

\footnotetext{
* Correspondence: mochizuki-my@pha.keio.ac.jp

'Division for Evaluation and Analysis of Drug Information, Faculty of Pharmacy, Keio University, 1-5-30 Shibakoen, Minato-ku, Tokyo 105-8512, Japan

Full list of author information is available at the end of the article
}

dementia, vascular dementia, or menopausal disorders. The standard composition of EGb761 preparations is $22.0 \%$ to $27.0 \%$ flavonoids and $5.0 \%$ to $7.0 \%$ terpenoids (ginkolides A, B, C; bilobalide; etc.) as active ingredients, and less than $5 \mathrm{ppm}$ of ginkgolic acid, which is an allergen. Flavonoids inactivate deleterious toxic active oxygen, and terpenoids act as antagonists of platelet activating factor and exert neuroprotection in the brain $[1,2]$. By combining these pharmacological activities, Ginkgo biloba is thought to improve memory and learning ability, blood flow in the microcirculation, hypoxia tolerance in brain cells, and blood viscosity due to its antioxidant, antiinflammatory, and other activities.

Although Ginkgo biloba extract has been reported to be effective in the treatment of vertigo [3], tinnitus [4], 
headache [5], and anxiety disorders [6] in clinical trials, consistent, conclusive results were not reported because of small sample sizes in many. Although there are a few meta-analyses [7-10] and a Cochran review [11] in the literature, they mainly focused on the efficacy of Ginkgo biloba rather than safety, except for the reviews by Jiang et al. [10] and Birks and Evans [11]. They evaluated multiple measures of cognitive outcome by extracting the results of the ADAS-Cog, SKT, etc. to determine efficacy.

Ginkgo biloba extract is sold as a health food product in Japan and as an over-the-counter (OTC) preparation in Germany. It would be safer if it were also sold as an OTC preparation under the management of healthcare professionals such as pharmacists in Japan. For the safe use of Ginkgo biloba extract products from the viewpoint of both patients and healthcare professionals, the risk-and-benefit balance is important. The aim of this study was therefore to evaluate both the efficacy based on a single measure of cognitive outcome and safety based on various outcomes of Ginkgo biloba in the treatment of dementia using the meta-analysis approach.

\section{Methods}

\section{Data sources}

To identify relevant clinical studies, an electronic search was conducted using MEDLINE (1966-January 2014), Embase (1974-January 2014), the Cochrane Library (Issue 1 of 12, January 2014), and Japana Centra Revuo Medicina (Ichushi) (1981-September 2014). The terms and study design used in the searches were "Ginkgo," or "icho" (in Japanese), "Alzheimer disease," "cognitive defect," "dementia," and "multiinfarct dementia," limited to "randomized controlled trial." In Ichushi, original articles and randomized controlled trials were searched under the type of article and study design. We imposed no language limitation in the searches. Additionally, a manual search of reference listings from all of the articles retrieved from the electronic databases was performed.

\section{Inclusion criteria}

The inclusion criteria of articles were that the studies: 1) were designed as double-blind, randomized, placebocontrolled trials; 2) had similar patients, study endpoints, dosage and administration, route of administration, duration of administration, etc.; 3) included patients with Alzheimer's disease (AD), vascular dementia (VaD), mixed dementia with $\mathrm{AD}$ and $\mathrm{VaD}$, and mild dementia. The standard mean difference (SMD) in the average value of the Syndrome Kurztest (SKT) [12] and Alzheimer's Disease Assessment Scale cognitive subscale (ADAS-Cog) [13] scores was used as the efficacy endpoint. The dropout rate and incidence of adverse events were used as safety endpoints. The primary outcome was the SMD of the average value of cognitive measures consisting of the SKT and ADAS-Cog, and dropout rate due to adverse events, respectively. Secondary outcomes included subanalysis of disease classification, dose, and administration duration for efficacy endpoints and dropout rate by reason and dose and incidence of adverse events for safety endpoints.

Three investigators ( $\mathrm{MH}, \mathrm{YO}, \mathrm{MS})$ applied the inclusion criteria independently to the articles retrieved. When disagreements occurred, all three conferred to arrive at a consensus. The quality of the studies retrieved was assessed using the Jadad score [14]. Only studies that received a score of 3 points or more were included in the meta-analysis. The three investigators scored the studies independently. When there was discordance among the quality scores reported by the three investigators, the lowest score was adopted.

\section{Data analyses}

In combing the data, efficacy in the treatment of dementia as evaluated by the SKT or ADAS-Cog in patients receiving Ginkgo biloba relative to those receiving placebo was calculated using the SMD [15]. Data were expressed as the SMD with 95\% confidence intervals (CI). We adopted the SMD rather than odds ratio (OR) because the SMD represents the actual difference in the antidementia effect, i.e., in the SKT or ADAS-Cog score as a clinical outcome endpoint, thus giving a more realistic picture of the impact of improvement as a clinically observable outcome. A negative value of the pooled SMDs indicates greater improvement of dementia symptoms in patients who received Ginkgo biloba therapy relative to those who did not, whereas a positive value indicates the opposite. The statistical significance of differences between groups was evaluated using the $95 \%$ CI. Standard errors and CIs were converted to standard deviation for the analyses. Apart from the SMD, side effects were analyzed in terms of ORs with 95\% CIs. For the metaanalysis, heterogeneity among studies was assessed using Q statistics, where a $P$ value less than 0.05 was considered significant. When no significant heterogeneity was observed regarding the risk estimates among the studies, the fixed-effects model was applied for further analysis [15]. When significant heterogeneity was observed, the random effects model was applied [15]. Calculations of pooled SMDs with 95\% CIs, as well as ORs with 95\% CIs, were performed with Review Manager 5.2 (Cochrane Collaboration, Oxford, UK). The heterogeneity of effect size among studies was tested. To assess potential publication bias, funnel plots for each outcome were also examined.

\section{Results}

Among the 298 studies retrieved from the electronic databases and those retrieved from their references by manual search, we identified 13 clinical studies that 
satisfied the predetermined inclusion criteria for our study (Figure 1, Table 1) [16-28]. While no language limitation for the systematic search was set, all relevant articles meeting the inclusion criteria were published in English. One group of authors divided the data from the same study and published them in four articles, as shown in Table 1. Finally, 9 clinical studies were used in the meta-analysis. All used EGb761, the standard extract of Ginkgo biloba, as the study drug, and the duration of administration ranged from 12 to 52 weeks; in 5 studies it was administered for 24 weeks. The daily dose ranged from 120 to $240 \mathrm{mg}: 120 \mathrm{mg}$ in 2 studies; $160 \mathrm{mg}$ in 2 studies; and $240 \mathrm{mg}$ in 7 studies. Three studies included only $\mathrm{AD}, 5$ included both $\mathrm{AD}$ and $\mathrm{VaD}$, and 1 included dementia excluding $\mathrm{AD}$ and $\mathrm{VaD}$. The clinical outcome endpoint was the SKT score in 7 studies and ADAS-Cog subscale score in 2 studies.

The quality of each article was evaluated according to the Jadad scoring system (Table 1) [14]. All 13 clinical studies were assessed as high quality ( $>3$ points), and 9 were included in the present meta-analysis, excluding the 4 reporting duplicated data.

For the SMD in the SKT, Forest plots of data from all patients, patients in the combined $\mathrm{AD}$ and $\mathrm{VaD}$ groups, patients in the $\mathrm{AD}$-alone groups, subanalysis by dose, and subanalysis by the duration of administration are shown in Figures 2,3,4,5 and 6, respectively. The change in scores for the SKT in all patients ranged from -3.3 to -0.9 in the Ginkgo biloba groups and from -1.2 to 1.3 in the placebo groups. The SMD (95\% CI) for the SKT in all patients were significantly greater for Ginkgo biloba than for placebo groups $(-0.90[-1.46,-0.34])$ (Figure 2). The change in SKT scores in combined $\mathrm{AD}$ and $\mathrm{VaD}$ ranged from -3.3 to -1.4 in the Ginkgo biloba and from -1.0 to 1.3 in the placebo groups. The SMD for the SKT in combined $\mathrm{AD}$ and $\mathrm{VaD}$ was significantly greater for Ginkgo biloba than for placebo groups $(-1.07[-1.66,-0.47])$ (Figure 3). Changes in scores in the SKT in AD ranged from -3.3 to -2.3 in the Ginkgo biloba groups and from 1.0 to 1.2 in the placebo groups. The SMD in the SKT in $\mathrm{AD}$ was significantly greater for Ginkgo biloba than for placebo $(-1.36[-2.27,-0.46]$ ) (Figure 4). By dose, the change in SKT scores at $160 \mathrm{mg} /$ day dose ranged from -3.3 to 0.7 in the Ginkgo biloba and from -1.2 to 1.0 in the placebo groups. The SMDs in the SKT at $160 \mathrm{mg} /$ day were greater for Ginkgo biloba than for placebo $(-1.06[-3.42,1.29])$. At $240 \mathrm{mg} /$ day, the SMDs in the SKT ranged from -3.2 to 1.0 in the Ginkgo biloba and from -1.2 to 1.3 in the placebo groups. The SMDs in the SKT at a dose of $240 \mathrm{mg} /$ day were significantly greater for Ginkgo biloba than for placebo $(-0.71[-1.28,-0.14])$ (Figure 5$)$. By treatment duration, the changes in SKT scores at 12 weeks was -2.89 in the Ginkgo biloba and 3.8 in the placebo groups. The SMD in the SKT at 12 weeks was greater for Ginkgo biloba than for placebo $(-1.09[-2.10,-0.08])$, and at 22-24 weeks ranged from -3.3 to -0.85 in the Ginkgo biloba and from 1.2 to 1.0 in the placebo groups. The SMDs in the SKT at 22-24 weeks were significantly greater for Ginkgo than for placebo $(-0.87[-1.46,-0.34])$ (Figure 6).

A Forest plot of the meta-analysis of the SMD in the ADAS-Cog at the dose of $120 \mathrm{mg}$ evaluated at 26 weeks is shown in Figure 7. The change in scores for the ADAS-

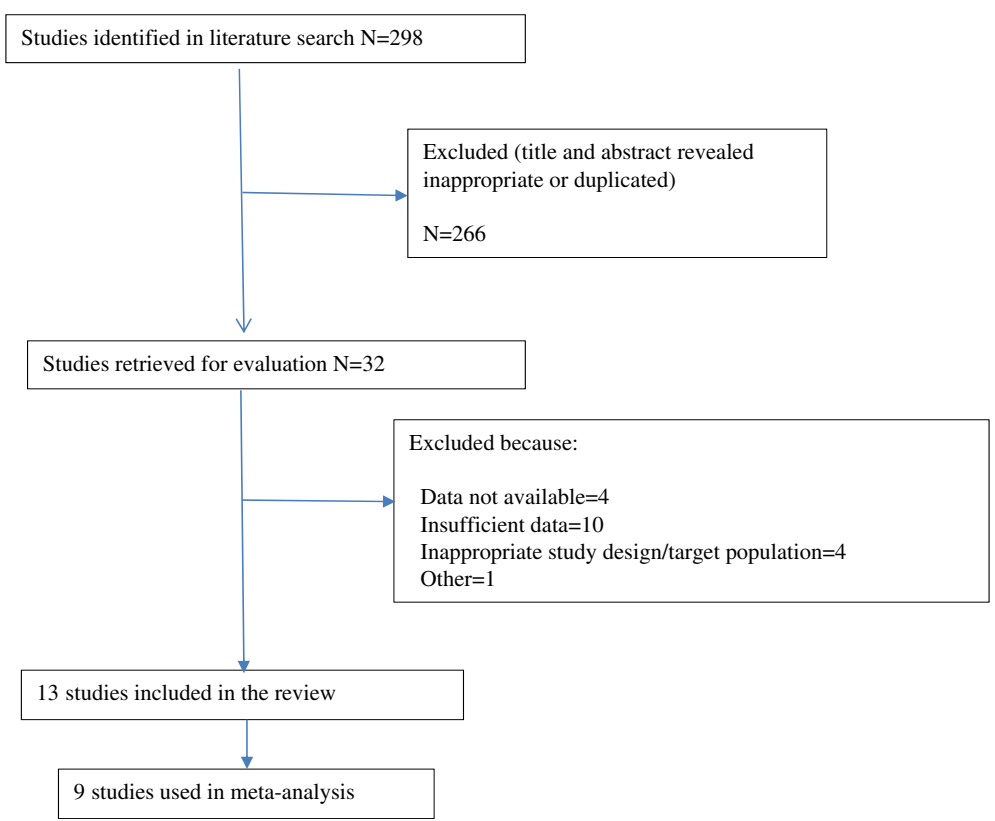

Figure 1 Study selection for inclusion in the present meta-analysis. 
Table 1 Summary of clinical studies meeting the initial inclusion criteria for this meta-analysis

\begin{tabular}{|c|c|c|c|c|c|c|c|c|c|}
\hline Study & $\begin{array}{l}\text { No. of patients and } \\
\text { treatment groups }\end{array}$ & $\begin{array}{l}\text { Duration } \\
\text { (weeks) }\end{array}$ & $\begin{array}{l}\text { Ginkgo biloba } \\
\text { dose (mg) }\end{array}$ & Age $(y)($ mean[SD]) & Gender female (\%) & Inclusion criteria & Endpoint & $\begin{array}{l}\text { Baseline cognitive } \\
\text { scale (mean [SD]) }\end{array}$ & $\begin{array}{l}\text { Jadad } \\
\text { score }\end{array}$ \\
\hline Herrschaft et al. [16] & $\begin{array}{l}\text { Total: } 402 \\
\text { EGb 761: } 200 \\
\text { Placebo: } 202\end{array}$ & 24 & $\begin{array}{l}\text { EGb 761: } \\
240 \\
\text { once daily }\end{array}$ & $\begin{array}{l}\text { Ginkgo: } 65.1 \text { (8.8) } \\
\text { Placebo: } 64.9 \text { (9.4) }\end{array}$ & $\begin{array}{l}\text { Ginkgo: } 139 \text { (69.5) } \\
\text { Placebo: } 140(69.3)\end{array}$ & $\begin{array}{l}\text { Probable AD by NINCDS-ADRDA } \\
\text { Possible AD with cerebrovascular } \\
\text { disorder by NINCDS-AIREN } \\
\text { Probable VaD by NINCDS-AIREN } \\
\text { SKT: } 9-23 \text { (moderate dementia), } \\
\text { HAMD <20 (except for serious } \\
\text { depression) }\end{array}$ & & $\begin{array}{l}\text { Ginkgo: } 15.1(4.1) \\
\text { Placebo: } 15.3(4.2)\end{array}$ & 4 \\
\hline Ihl et al. [17] & $\begin{array}{l}\text { Total: } 404 \\
\text { EGb 761: } 202 \\
\text { Placebo: } 202\end{array}$ & 24 & $\begin{array}{l}\text { EGb 761: } \\
240 \\
\text { once daily }\end{array}$ & $\begin{array}{l}\text { Ginkgo: } 65.0(10.0) \\
\text { Placebo: } 65.0(9.0)\end{array}$ & $\begin{array}{l}\text { Ginkgo: } 139 \text { (69) } \\
\text { Placebo: } 133 \text { (66) }\end{array}$ & $\begin{array}{l}\text { Probable AD by NINCDS-ADRDA } \\
\text { Possible AD with cerebrovascular } \\
\text { disorder by NINCDS-AIREN } \\
\text { Probable VaD by NINCDS-AIREN } \\
\text { SKT: } 9-23 \text { (mild-moderate dementia), } \\
\text { MMSE: } 14-25 \text {, ADAS-Cog: } 17-35\end{array}$ & & $\begin{array}{l}\text { Ginkgo: } 16.7(3.9) \\
\text { Placebo: } 17.2(3.7)\end{array}$ & 4 \\
\hline Ihl et al. [18] & $\begin{array}{l}\text { Total: } 404 \\
\text { EGb 761: } 202 \\
\text { (AD 163, VaD 39) } \\
\text { Placebo: 202 } \\
\text { (AD 170, VaD 32) }\end{array}$ & 24 & $\begin{array}{l}\text { EGb 761: } \\
240 \\
\text { once daily }\end{array}$ & $\begin{array}{l}\text { AD: } \\
\text { Ginkgo: } 64.9(9.5) \\
\text { Placebo: } 64.2(8.7) \\
\text { VaD: } 65.8(10.0) \\
\text { Placebo: } 66.5(10.7)\end{array}$ & $\begin{array}{l}\text { AD: } \\
\text { Ginkgo: } 109(66.9) \\
\text { Placebo: } 111(65.3) \\
\text { VaD: } \\
\text { Ginkgo: } 30(76.9) \\
\text { Placebo: } 22(68.8)\end{array}$ & $\begin{array}{l}\text { Probable AD by NINCDS-ADRDA } \\
\text { Possible AD with cerebrovascular } \\
\text { disorder by NINCDS-AIREN } \\
\text { Probable VaD by NINCDS-AIREN } \\
\text { SKT: 9-23 (mild-moderate dementia), } \\
\text { MMSE: } 14-25 \text {, ADAS-Cog: } 17-35\end{array}$ & SKT & $\begin{array}{l}\text { AD: } \\
\text { Ginkgo: } 16.4(3.8) \\
\text { Placebo: } 17.0(3.8) \\
\text { VaD: } \\
\text { Ginkgo: } 17.8(3.9) \\
\text { Placebo: } 18.3(3.4)\end{array}$ & 4 \\
\hline Napryeyenko et al. [19] & $\begin{array}{l}\text { Total: } 395 \\
\text { EGb 761: } 198 \\
\text { Placebo: } 197\end{array}$ & 22 & $\begin{array}{l}\text { EGb 761: } \\
240 \\
\text { twice daily }\end{array}$ & $\begin{array}{l}\text { Ginkgo: } 65.0 \text { (8.0) } \\
\text { Placebo: } 63.0(8.0)\end{array}$ & $\begin{array}{l}\text { Ginkgo: } 143 \text { (72) } \\
\text { Placebo: } 142 \text { (72) }\end{array}$ & $\begin{array}{l}\text { Probable AD by NINCDS-ADRDA } \\
\text { Possible AD with cerebrovascular } \\
\text { disorder by NINCDS-AIREN } \\
\text { Probable VaD by NINCDS-AIREN } \\
\text { SKT: 9-23 (mild-moderate dementia), } \\
\text { MMSE: } 14-25 \text {, ADAS-Cog: } 17-35\end{array}$ & & $\begin{array}{l}\text { Ginkgo: } 15.6(3.9) \\
\text { Placebo: } 15.4(3.7)\end{array}$ & 5 \\
\hline Napryeyenko et al. [20] & $\begin{array}{l}\text { Total: } 400 \\
\text { EGb 761: } 200 \\
\text { (AD 106, VaD 94; } \\
\text { Dropped, AD 2) } \\
\text { Placebo: } 200 \\
\text { (AD 112, VaD 88; } \\
\text { Dropped, AD 2, } \\
\text { VaD 1) }\end{array}$ & 22 & $\begin{array}{l}\text { EGb 761: } \\
240 \\
\text { twice daily }\end{array}$ & $\begin{array}{l}\text { AD: } \\
\text { Ginkgo: } 66.0(8.0) \\
\text { Placebo: } 64.0(8.0) \\
\text { VaD: } \\
\text { Ginkgo: } 63.0(8.0) \\
\text { Placebo: } 63.0(9.0)\end{array}$ & $\begin{array}{l}\text { AD: } \\
\text { Ginkgo: } 70(67) \\
\text { Placebo: } 78(71) \\
\text { VaD: } \\
\text { Ginkgo: } 73 \text { (78) } \\
\text { Placebo: } 64(74)\end{array}$ & $\begin{array}{l}\text { Probable AD by NINCDS-ADRDA } \\
\text { Possible AD with cerebrovascular } \\
\text { disorder by NINCDS-AIREN } \\
\text { Probable VaD by NINCDS-AIREN } \\
\text { SKT: 9-23 (mild-moderate dementia), } \\
\text { MMSE: } 14-25 \text {, ADAS-Cog: 17-35 }\end{array}$ & & $\begin{array}{l}\text { AD: } \\
\text { Ginkgo: } 16.4(3.8) \\
\text { Placebo: } 15.8(3.8) \\
\text { VaD: } \\
\text { Ginkgo: } 14.8(3.8) \\
\text { Placebo: } 15.0(3.6)\end{array}$ & 5 \\
\hline Mazza et al. [21] & $\begin{array}{l}\text { Total: } 51 \\
\text { EGb: } 25 \\
\text { Placebo: } 26\end{array}$ & 24 & EGb:160 & $\begin{array}{l}\text { Ginkgo: } 66.2(6.0) \\
\text { Placebo: } 69.8(3.0)\end{array}$ & $\begin{array}{l}\text { Ginkgo: } 13(52) \\
\text { Placebo: } 16(61)\end{array}$ & $\begin{array}{l}\text { AD by DSM-IV } \\
\text { SKT: } 8-23, \text { MMSE: } 13-25, \text { IQ }>80 \text {, } \\
\text { GDS }<11 \text { (except for serious } \\
\text { depression) }\end{array}$ & & $\begin{array}{l}\text { Ginkgo: } 16.45 \text { (3.05) } \\
\text { Placebo: } 15.90(3.86)\end{array}$ & 4 \\
\hline Kanowski et al. [22] & $\begin{array}{l}\text { Total: } 205 \\
\text { EGb 761: } 106 \\
\text { Placebo: } 99 \\
\text { AD: } 158 \mathrm{E} \\
\text { Gb 761: } 79 \\
\text { Placebo: } 79\end{array}$ & 24 & $\begin{array}{l}\text { EGb 761: } \\
240 \\
\text { twice daily }\end{array}$ & $\begin{array}{l}\text { Ginkgo: } 72.0(10.0) \\
\text { Placebo: } 72.0(10.0)\end{array}$ & $\begin{array}{l}\text { Ginkgo: } 72 \text { (68) } \\
\text { Placebo: } 70 \text { (71) }\end{array}$ & $\begin{array}{l}\text { AD or multiinfarct dementia by } \\
\text { DSM-III-R } \\
\text { SKT: 6-18, MMSE: } 13-25\end{array}$ & & $\begin{array}{l}\text { Ginkgo: } 10.5(3.2) \\
\text { Placebo: } 11.2(3.3)\end{array}$ & 4 \\
\hline
\end{tabular}


Table 1 Summary of clinical studies meeting the initial inclusion criteria for this meta-analysis (Continued)

\begin{tabular}{|c|c|c|c|c|c|c|c|c|c|}
\hline van Dongen et al. [23] & $\begin{array}{l}\text { Total: } 123 \\
\text { EGb } 761(240 \mathrm{mg}): 39 \\
\text { EGb } 761(160 \mathrm{mg}): 40 \\
\text { Placebo: } 44\end{array}$ & 24 & $\begin{array}{l}\text { EGb 761: } \\
240 \text { (high dose) } \\
160 \text { (low dose) }\end{array}$ & $\begin{array}{l}\text { Ginkgo: } 82.6(5.1) \\
\text { Placebo: } 82.5 \text { (5.8) }\end{array}$ & $\begin{array}{l}\text { Ginkgo: } 68 \text { (86) } \\
\text { Placebo: } 36 \text { (82) }\end{array}$ & $\begin{array}{l}\text { AD, VaD, mixed type, memory } \\
\text { disorder with aging, early dementia } \\
\text { patients (comparatively slight } \\
\text { dementia, if the effect of Ginkgo } \\
\text { biloba is marked) by DSM--1II-R, } \\
\text { ICD-10 } \\
\text { SKT: 8-23, GDS <11 (except for } \\
\text { serious depression), IQ > } 80 \text {, MMSE: } \\
\text { 9-26 }\end{array}$ & & $\begin{array}{l}\text { Ginkgo: } 15.6(4.1) \\
\text { Placebo: } 14.1(4.6)\end{array}$ & 4 \\
\hline Maurer et al. [24] & $\begin{array}{l}\text { Total: } 18 \\
\text { EGb } 761: 9 \\
\text { Placebo: } 9\end{array}$ & 12 & $\begin{array}{l}\text { EGb 761: } \\
240\end{array}$ & $\begin{array}{l}\text { Ginkgo: } 68.5(6.0) \\
\text { Placebo: } 60.6(8.82)\end{array}$ & $\begin{array}{l}\text { Ginkgo: } 5 \text { (56) } \\
\text { Placebo: } 4 \text { (44) }\end{array}$ & $\begin{array}{l}\text { AD, probable AD by DSM-III-R, } \\
\text { NINCDS-ADRDA }\end{array}$ & & $\begin{array}{l}\text { Ginkgo: } 19.67(6.31) \\
\text { Placebo: } 18.11(9.43)\end{array}$ & 4 \\
\hline Schneider et al. [25] & $\begin{array}{l}\text { Total: } 513 \\
\text { EGb } 761 \text { ( } 240 \mathrm{mg}): 170 \\
\text { EGb } 761 \text { (120 mg): } 169 \\
\text { Placebo: } 174\end{array}$ & 26 & $\begin{array}{l}\text { EGb 761: } \\
240 \\
120 \\
\text { twice daily }\end{array}$ & $\begin{array}{l}\text { Ginkgo: } \\
240 \text { mg: } 78.1(7.0) \\
120 \text { mg: } 78.6(7.0) \\
\text { Placebo: } 77.5(7.4)\end{array}$ & $\begin{array}{l}\text { Ginkgo: } \\
240 \text { mg: } 96(56) \\
120 \text { mg: } 84(50) \\
\text { Placebo: } 90 \text { (52) }\end{array}$ & $\begin{array}{l}\text { AD by DSM-IV } \\
\text { Probable AD by NINCDS-ADRDA } \\
\text { MMSE: } 10-24 \text { (to prevent excess } \\
\text { evaluation, } \geq 20 \text { not included) }\end{array}$ & & $\begin{array}{l}\text { Ginkgo (240 mg): } 24.8 \text { (12.7) } \\
\text { Ginkgo (120 mg): } 24.7(11.9) \\
\text { Placebo: } 25.01 \text { (11.1) }\end{array}$ & 5 \\
\hline Le Bars et al. [26] & $\begin{array}{l}\text { Total: } 309 \\
\text { EGb: } 155 \\
\text { Placebo: } 154\end{array}$ & 26,52 & EGb: 120 & $\begin{array}{l}\text { Ginkgo: } 69.0(10.0) \\
\text { Placebo: } 69.0(10.0)\end{array}$ & $\begin{array}{l}\text { Ginkgo: } 79(51) \\
\text { Placebo: } 87 \text { (56) }\end{array}$ & $\begin{array}{l}\text { Uncomplicated AD or multiinfarct } \\
\text { dementia by DSM-III-R, ICD-10 AD } \\
\text { MMSE: 9-26, GDS: 3-6 }\end{array}$ & & $\begin{array}{l}\text { Ginkgo: } 20.0(16.0) \\
\text { Placebo: } 20.5 \text { (14.7) }\end{array}$ & 3 \\
\hline Le Bars et al. [27] & $\begin{array}{l}\text { Total: } 309 \text { (AD: 236) } \\
\text { EGb 761: } 155 \text { (AD: 120) } \\
\text { Placebo: } 154 \text { (AD: 116) } \\
\text { At 26-week endpoint: } \\
\text { EGb 761: } 136 \\
\text { Placebo: } 134\end{array}$ & 26 & $\begin{array}{l}\text { EGb 761: } \\
120\end{array}$ & $\begin{array}{l}\text { All: } \\
\text { Ginkgo: } 69.0(10.0) \\
\text { Placebo: } 69.0(10.0) \\
\text { AD: } \\
68.0 \text { (10.0) } \\
\text { Placebo: } 68.0(11.0)\end{array}$ & $\begin{array}{l}\text { All: } \\
\text { Ginkgo: } 79(51) \\
\text { Placebo: } 87 \text { (56) } \\
\text { AD: } 65 \text { (54) } \\
\text { Placebo: } 72 \text { (62) }\end{array}$ & $\begin{array}{l}\text { Uncomplicated AD or multiinfarct } \\
\text { dementia by DSM-III-R, ICD-10 AD } \\
\text { MMSE: 9-26, GDS: 3-6 }\end{array}$ & ADAS- Cog & $\begin{array}{l}\text { All: } \\
\text { Ginkgo: } 20.0(16.0) \\
\text { Placebo: } 20.5(14.7) \\
\text { AD: } \\
\text { Ginkgo: } 19.7(16.4) \\
\text { Placebo: } 20.2(15.2)\end{array}$ & 3 \\
\hline Le Bars et al. [28] & $\begin{array}{l}\text { Total: } 236 \\
\text { MMSE }>23 \\
\text { EGb 761: } 61 \\
\text { Placebo: } 61 \\
\text { MMSE <24 } \\
\text { EGb 761: } 59 \\
\text { Placebo: } 55\end{array}$ & 52 & $\begin{array}{l}\text { EGb 761: } \\
120\end{array}$ & $\begin{array}{l}\text { MMSE >23: } \\
\text { Ginkgo: } 64.0(9.0) \\
\text { Placebo: } 64.0(11.0) \\
\text { MMSE <24: } \\
\text { Ginkgo: } 73.0(9.0) \\
\text { Placebo: } 72.0(9.0)\end{array}$ & $\begin{array}{l}\text { MMSE >23: } \\
\text { Ginkgo: } 34 \text { (56) } \\
\text { Placebo: } 38 \text { (62) } \\
\text { MMSE <24: } \\
\text { Ginkgo: } 31 \text { (53) } \\
\text { Placebo: } 34 \text { (62) }\end{array}$ & $\begin{array}{l}\text { Uncomplicated AD or multiinfarct } \\
\text { dementia by DSM-III-R, ICD-10 AD } \\
\text { MMSE: 9-26, GDS: 3-6 }\end{array}$ & & $\begin{array}{l}\text { MMSE >23: } \\
\text { Ginkgo: } 9.0(4.0) \\
\text { Placebo: } 10.1(4.9) \\
\text { MMSE <24: } \\
\text { Ginkgo: } 31.1(17.0) \\
\text { Placebo: } 31.9(14)\end{array}$ & 3 \\
\hline
\end{tabular}

NINCDS-ADRDA: Diagnosis criteria by the National Institute of Neurological and Communicative Disorders and Stroke (NINCDS) and the Alzheimer's Disease and Related Disorders Association (ADRDA) working group. AIREN: Diagnostic criteria for vascular dementia by the Association Internationale pour la Recherche et 1'Enseignement en Neurosciences (AIREN). HAMD: Hamilton Rating Scale for Depression. MMSE: Mini-Mental State Examination. IQ: intelligence quotient. GDS: Geriatric Depression Scale. 


\begin{tabular}{|c|c|c|c|c|c|c|c|c|c|}
\hline \multirow[b]{2}{*}{ Study or Subgroup } & \multicolumn{3}{|c|}{ ginkgo } & \multicolumn{3}{|c|}{ placobo } & \multicolumn{2}{|r|}{ Std. Mean Difference } & \multirow{2}{*}{$\begin{array}{l}\text { Std. Mean Difference } \\
\text { IV, Random, } 95 \% \mathrm{Cl}\end{array}$} \\
\hline & Mean & SD & Total & Mean & SD & Total & Weight & IV, Random, $95 \% \mathrm{Cl}$ & \\
\hline Herrschaft 2012 & -2.2 & 3.59 & 200 & -0.3 & 4.32 & 202 & $15.6 \%$ & $-0.48[-0.68,-0.28]$ & 可 \\
\hline Ihl 2011 & -1.4 & 2.88 & 202 & 0.3 & 2.88 & 202 & $15.6 \%$ & $-0.59[-0.79,-0.39]$ & $=$ \\
\hline Kanorski 2003 & -2.1 & 3.12 & 106 & -1 & 3.79 & 99 & $15.3 \%$ & $-0.32[-0.59,-0.04]$ & 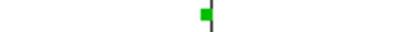 \\
\hline Maurer 1997 & -2.9 & 2.5 & 9 & 0.8 & 3.8 & 9 & $10.5 \%$ & $-1.10[-2.10,-0.09]$ & $\rightarrow-1$ \\
\hline Mazza 2006 & -3.3 & 2 & 25 & 1 & 1.7 & 26 & $12.6 \%$ & $-2.28[-3,00,-1.57]$ & -1 \\
\hline Napryeyenko 2007 & -3.2 & 2.3 & 198 & 1.3 & 2.4 & 197 & $15.5 \%$ & $-1.91[-2.15,-1.67]$ & " \\
\hline Van Dongen 2003 & -0.9 & 4.2 & 79 & -1.2 & 3.8 & 44 & $14.9 \%$ & $0.07[-0.30,0.44]$ & + \\
\hline Total $(95 \% \mathrm{Cl})$ & & & 819 & & & 779 & $100.0 \%$ & $-0.90[-1.46,-0.34]$ & $\boldsymbol{\gamma}$ \\
\hline \multicolumn{9}{|c|}{$\begin{array}{l}\text { Heterogeneity: } \text { Tau }^{2}=0.51 ; \text { Chi }^{2}=147.49, \mathrm{df}=6(P< \\
\text { Test for overall effect: } Z=3.16(P=0.002)\end{array}$} & 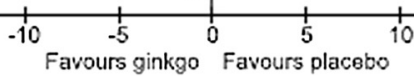 \\
\hline
\end{tabular}

Cog ranged from -0.3 to 1.6 in the Ginkgo biloba and from 0.9 to 1.0 in the placebo groups. The SMD in the SKT at 26 weeks and $120 \mathrm{mg} /$ day were greater for Ginkgo biloba than for placebo $(-0.06[-0.41,0.30])$, but the difference did not reach statistical significance.

For the safety analysis, the data of side effect with an incidence of at least more than 3\% from initiation of treatment within 2 days after completion of treatment described in each report was extracted and analyzed. A Forest plot of the dropout rate for any reason and subanalysis by dose are shown in Figure 8. The change in the OR $(95 \% \mathrm{CI})$ for the dropout rate was lower for Ginkgo biloba than for placebo $(\mathrm{OR}=0.85[0.68,1.06])$ but was not statistically significant. Subanalysis showed that the change in the OR for the dropout rate for any reason by dose was lower for Ginkgo biloba than for placebo (OR $=0.70[0.49,1.01]$ at $120 \mathrm{mg} /$ day and $\mathrm{OR}=0.76[0.29$, 1.98 ] at $160 \mathrm{mg} /$ day), but the difference was not statistically significant. At the dose of $240 \mathrm{mg} /$ day, Ginkgo biloba and placebo were nearly equivalent $(\mathrm{OR}=1.02$ $[0.74,1.41])$. Forest plots of the dropout rate due to side effects and subanalysis by dose are shown in Figures 9 and 10, respectively. The change in the OR for the dropout rate due to side effects was significantly higher for Ginkgo biloba than for placebo (OR $=1.83[1.04,3.22])$. Subanalysis of the change in the OR for the dropout rate due to side effects and dose was also higher for the Ginkgo biloba than for the placebo groups $(\mathrm{OR}=1.54$
$[0.77,3.10]$ at $120-160 \mathrm{mg} /$ day and $\mathrm{OR}=1.90[0.96$, $3.77]$ at $240 \mathrm{mg} /$ day), but the difference was not statistically significant.

The number and type of severe side effects are shown in Figure 11, and the incidence of side effects reported in more than $3 \%$ of patients is given in Figure 12. Headache, dizziness, and pulmonary infections occurred in 4 studies, and elevation of blood pressure and tinnitus in 3. Meta-analysis was performed for each of these side effects. The change in the OR for the incidence of severe side effects was lower for the Ginkgo biloba than for the placebo groups $(\mathrm{OR}=0.77[0.47,1.26])$, but the difference did not reach statistical significance. Subanalysis of the change in the OR by daily dose showed that Ginkgo biloba and placebo were nearly equivalent $(\mathrm{OR}=0.95$ $[0.43,2.09]$ at $120 \mathrm{mg} /$ day). The change in the OR at the dose of $240 \mathrm{mg} /$ day was lower for Ginkgo biloba than for placebo $(\mathrm{OR}=0.67[0.36,1.27])$, but not statistically significant. By specific side effects, the change in the OR for the incidence of headache was lower for Ginkgo biloba than for placebo $(\mathrm{OR}=0.75[0.44,1.28])$, but not significantly (Figure 12). The incidence of dizziness was significantly lower in the Ginkgo biloba than in the placebo groups $(\mathrm{OR}=0.50[0.35,0.73])$ (Figure 12). The incidence of infectious pulmonary disease was almost the same in the 2 groups $(\mathrm{OR}=1.04[0.71,1.54])$, with no statistically significant difference (Figure 12). Although elevation of blood pressure occurred less frequently in

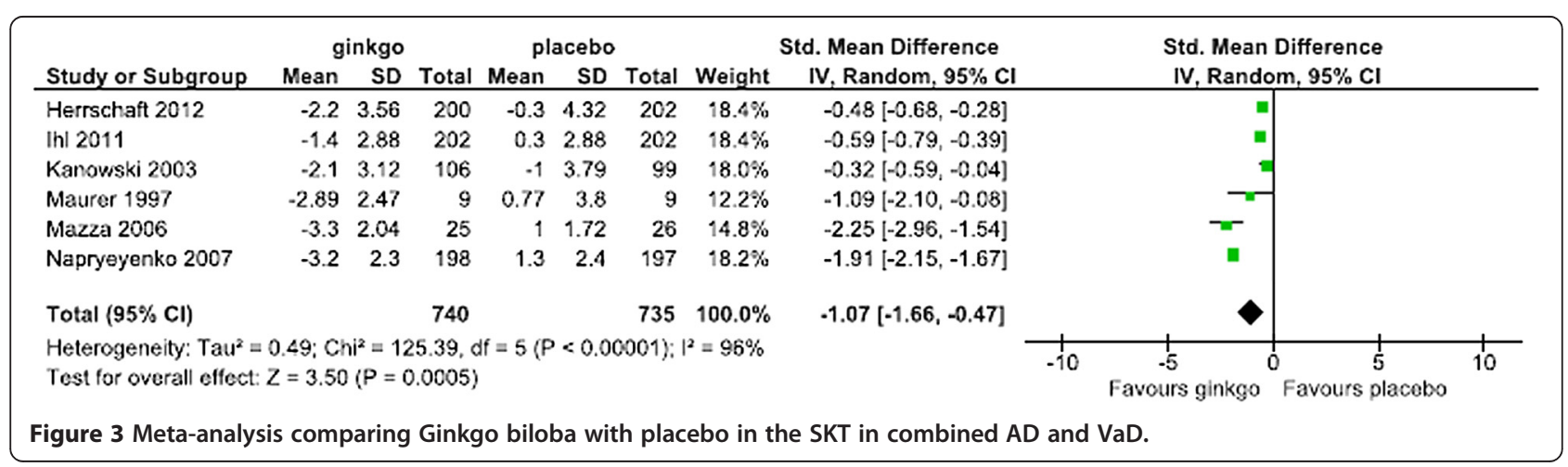




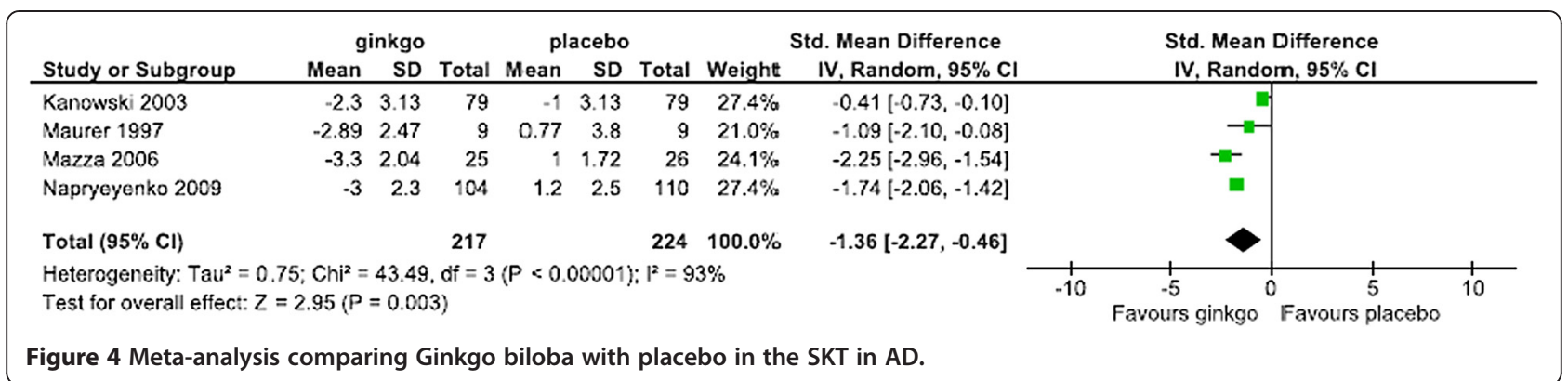

the Ginkgo biloba than in the placebo groups (OR $=0.72$ $[0.44,1.16])$, the difference was not significant (Figure 12). However, the incidence of tinnitus was significantly lower in the Ginkgo biloba than in the placebo groups ( $\mathrm{OR}=$ $0.38[0.22,0.67]$ ) (Figure 12).

Funnel plots for each outcome showed that there was no publication bias that could have affected the results of this meta-analysis.

\section{Discussion}

Many clinical studies and several meta-analyses have shown the efficacy of Ginkgo biloba for the treatment of neuropsychiatric disorders, but almost all previous meta-analyses evaluated multiple measures of cognitive outcome by extracting the ADAS-Cog, SKT, etc. results as a marker of efficacy and did not evaluate the detailed safety outcomes. Therefore, a final conclusion has not been reached on its benefits as a medicine based on the balance between efficacy and safety. For the safe use of Ginkgo biloba extract products from the viewpoint of both patients and healthcare professionals, it is important to know the risk-and-benefit balance and the most effective method of administration in patients with dementia. By evaluating both the efficacy by a single measure of cognitive outcome and safety by detailed safety outcomes of Ginkgo biloba, this meta-analysis yielded results similar to previous ones and suggested that Ginkgo biloba has therapeutic potential for the treatment of dementia.

Thirteen clinical studies retrieved from the literature satisfied the predetermined inclusion criteria, and 9 were used in the present meta-analysis, excluding 4 reports based on the same data. Previous meta-analyses included 6-9 clinical studies of dementia. Disease classification in our meta-analysis included 3 reports on $\mathrm{AD}$ alone, 5 on combined $\mathrm{AD}$ and $\mathrm{VaD}$, and 1 report on other dementia. The meta-analysis results for the SMD in the SKT between Ginkgo biloba and placebo in all patients, the AD and $\mathrm{VaD}$ combined group, and $\mathrm{AD}$-alone group showed a statistically significant difference favoring Ginkgo biloba over placebo. Because a higher SKT score indicates a more severe level of dementia [29], these results suggest that Ginkgo biloba can improve the symptoms of AD and/or $\mathrm{VaD}$. They were generally consistent with the results of

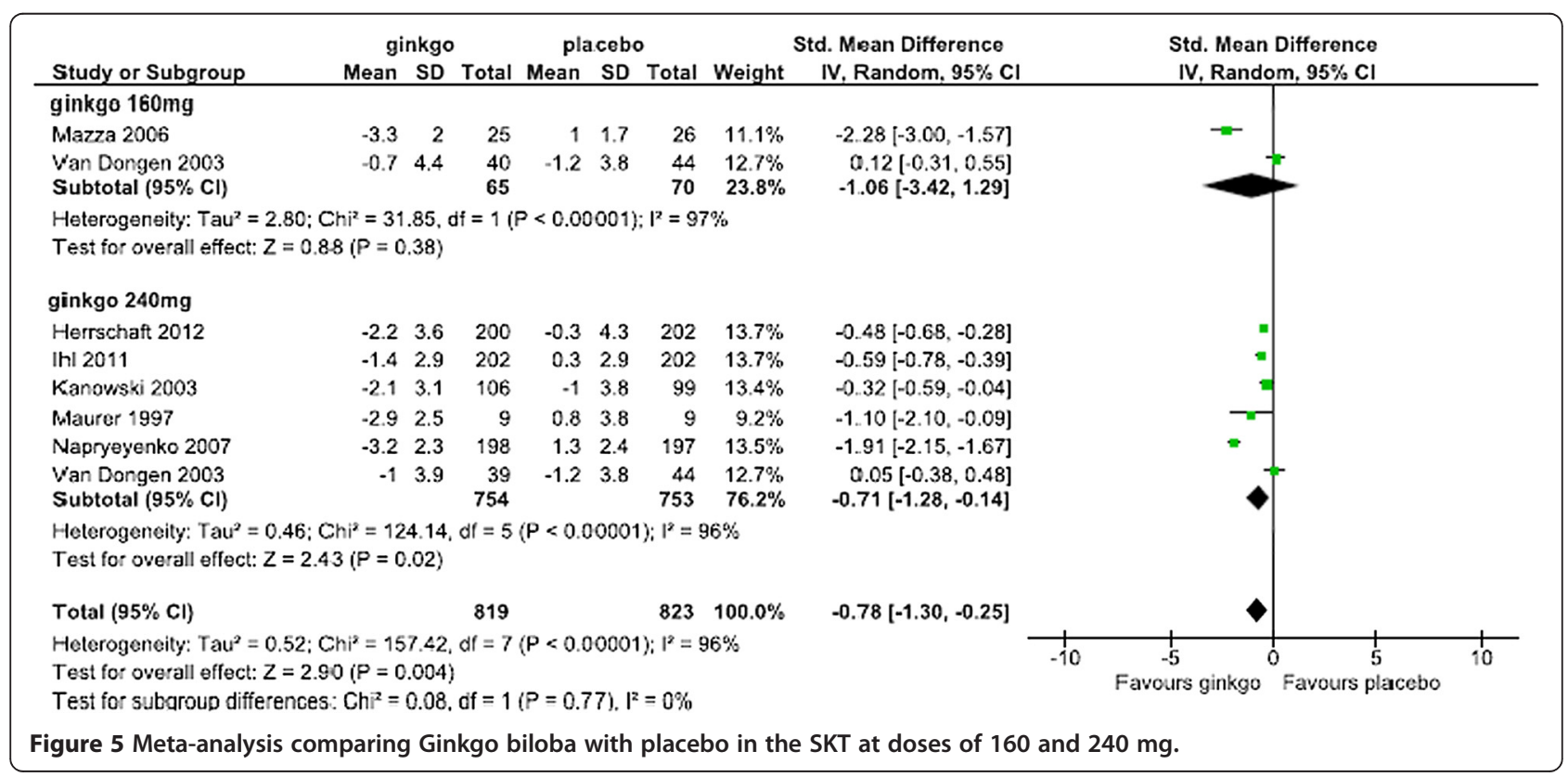




\begin{tabular}{|c|c|c|c|c|c|c|c|c|c|c|c|c|}
\hline Study or Subgroup & \multicolumn{2}{|c|}{ ginkgo } & \multicolumn{4}{|c|}{ placobo } & \multicolumn{2}{|c|}{ Std. Mean Difference } & \multicolumn{4}{|c|}{$\begin{array}{l}\text { Std. Mean Difference } \\
\text { IV. Random. } 95 \% \mathrm{Cl}\end{array}$} \\
\hline \multicolumn{13}{|l|}{12 wesk } \\
\hline $\begin{array}{l}\text { Maurer } 1997 \\
\text { Subtotal }(95 \% \mathrm{Cl})\end{array}$ & -2.89 & 2.47 & $\begin{array}{l}9 \\
9\end{array}$ & 0.77 & 3.8 & $\begin{array}{l}9 \\
9\end{array}$ & $\begin{array}{l}10.5 \% \\
10.5 \%\end{array}$ & $\begin{array}{l}-1.09[-2.10,-0.08] \\
-1.09[-2.10,-0.08]\end{array}$ & & & & \\
\hline \multicolumn{13}{|c|}{$\begin{array}{l}\text { Heterogeneity: Not applicable } \\
\text { Test for overall effect: } Z=2.12\langle P=0.03\rangle\end{array}$} \\
\hline \multicolumn{13}{|l|}{ 22 24week } \\
\hline Herrschaft 2012 & -2.2 & 3.59 & 200 & -0.3 & 4.32 & 202 & $15.6 \%$ & $-0.48[-0.68,-0.28]$ & & 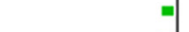 & & \\
\hline In| 2011 & -1.4 & 2.89 & 202 & 0.3 & 2.88 & 202 & $15.6 \%$ & $-0.59[-0.79,-0.39]$ & & - & & \\
\hline Kanouski 2003 & -2.1 & 3.12 & 106 & -1 & 3.79 & 99 & $15.3 \%$ & $-0.32[-0.59,-0.04]$ & & & & \\
\hline Mazza 2006 & -3.3 & 2.04 & 25 & 1 & 1.72 & 26 & $12.6 \%$ & $-2.25[-2.96,-1.54]$ & & -- & & \\
\hline Napryoyenko 2007 & -32 & 2.3 & 198 & 1.3 & 2.4 & 197 & $15.5 \%$ & $-1.91[-2.15,-1.67]$ & & " & & \\
\hline $\begin{array}{l}\text { Van Dongen } 2003 \text { (All dose) } \\
\text { Subtotal }(95 \% \mathrm{Cl})\end{array}$ & -0.85 & 4.2 & $\begin{array}{r}79 \\
810\end{array}$ & -1.2 & 3.8 & $\begin{array}{r}44 \\
770\end{array}$ & $\begin{array}{l}14.9 \% \\
89.5 \%\end{array}$ & $\begin{array}{r}0.09[-0.28,0.45] \\
-0.87[-1.47,-0.28]\end{array}$ & & & & \\
\hline \multicolumn{13}{|c|}{$\begin{array}{l}\text { Heterogeneity: } \text { Tau }^{2}=0.52 ; \mathrm{Chi}^{2}=147.06, \mathrm{df}=5(\mathrm{P}<0.00001) ; \mathrm{I}^{2}=97 \% \\
\text { Test for overall effect: } Z=2.87(P=0.004)\end{array}$} \\
\hline Total $(95 \% \mathrm{Cl})$ & & & 819 & & & 779 & $100.0 \%$ & $-0.90[-1.46,-0.34]$ & & $>$ & & \\
\hline $\begin{array}{l}\text { Heterogeneity: } \operatorname{Tau}^{2}=0.51 \text {; } \\
\text { Test for overall effect: } Z=3 \text {. } \\
\text { Test for subgroup differences }\end{array}$ & $\begin{array}{l}\mathrm{h}^{2}=147 \\
\langle P=0 . \\
\mathrm{Ch}^{2}=0\end{array}$ & $\begin{array}{l}7.47, \mathrm{~d} \\
002) \\
0.13 \mathrm{~d}\end{array}$ & $\begin{array}{l}f=6(P \\
f=1(P\end{array}$ & $\begin{array}{l}0<0.000 \\
=0.72\end{array}$ & $1^{2}=0$ & $\begin{array}{l}2=96 \% \\
0 \%\end{array}$ & & & -10 & Favours ginkgo & Favours placebo & 10 \\
\hline
\end{tabular}

the Cochrane review reported in 2009, in which the SMD was -1.30 (95\% CI: $-3.10,0.50]$ [11].

When conducting subgroup analysis by dose, the SMD (95\% CI) in the SKT at $160 \mathrm{mg}$ and $240 \mathrm{mg}$ were -1.06 $(-3.42,1.29)$ and $-0.71(-1.28,-0.14)$, respectively, with a statistically significant difference only between the latter and placebo. Jiang et al. [10] reported a similar result when comparing changes in cognitive scores in patients who received Ginkgo biloba $>200 \mathrm{mg} /$ day and $<200 \mathrm{mg} /$ day. The effects of Ginkgo biloba on the central nervous system as measured in the brain wave test suggested dose responsiveness [30], and the present results may partially support that although we found no clear doseresponse difference between the doses of $160 \mathrm{mg}$ and $240 \mathrm{mg}$ daily.

There was no statistically significant difference in the ADAS-Cog results $(-0.06[-0.41,0.30])$ in our metaanalysis, although a tendency toward improvement was noted in the Ginkgo biloba group. Two studies included in this meta-analysis had similar patient numbers but conflicting ADAS-Cog results. A possible reason for this may have been differing diagnostic criteria and the dosage used. The dose in both of those studies was $120 \mathrm{mg}$ daily, while our SKT results indicated the efficacy of Ginkgo biloba $240 \mathrm{mg}$ daily. It appears likely that a full response was not achieved with a daily dose of $120 \mathrm{mg}$.

The dropout rate for any reason in all combined studies had an OR of 0.85 (95\% CI: 0.67, 1.08) and the dropout rate at doses of $120 \mathrm{mg} /$ day, $160 \mathrm{mg} /$ day, and 240 $\mathrm{mg} /$ day, which showed efficacy in the SKT results, were $0.70(0.49,1.01), 0.76(0.29,1.98)$, and $1.02(0.74,1.41)$, respectively. None of the studies at doses of $120 \mathrm{mg} /$ day, $160 \mathrm{mg} /$ day, and $240 \mathrm{mg} /$ day in this meta-analysis showed a statistically significant difference in dropout rates for any reason compared with placebo. The OR of the dropout rate due to side effects in all combined studies was 1.83 $(1.04,3.22)$ and there was a statistically significant difference between Ginkgo biloba and placebo. Although there was no significant difference between Ginkgo biloba and placebo in subanalysis of the doses of 120-160 mg/day and $240 \mathrm{mg} /$ day, these data showed that the incidence of side effects in Ginkgo biloba groups tended to be higher than that in placebo groups. A tendency for a doseresponse relationship in the dropout rate due to side effects was also suggested.

There was no significant difference between the Ginkgo biloba and placebo groups in the occurrence of severe side effects, in the incidence of side effects reported in 3 or

\begin{tabular}{|c|c|c|c|c|c|c|c|c|c|}
\hline \multirow[b]{2}{*}{ Study or Subgroup } & \multicolumn{3}{|c|}{ ginkgo } & \multicolumn{3}{|c|}{ placebo } & \multirow{2}{*}{ Woight } & \multirow{2}{*}{$\begin{array}{l}\text { Std. Mean Difference } \\
\text { IV, Random, } 95 \% \mathrm{Cl}\end{array}$} & \multirow{2}{*}{$\begin{array}{l}\text { Std. Mean Difference } \\
\text { IV. Random, } 95 \% \mathrm{Cl}\end{array}$} \\
\hline & Mean & SD & Total & Mean & SD & Total & & & \\
\hline Le Bars 2000 & -0.3 & 5.4 & 136 & 1 & 5.3 & 134 & $48.8 \%$ & $-0.24[-0.48,-0.00]$ & \\
\hline Schneider 2005 & 1.6 & 5.8 & 169 & 0.9 & 5.6 & 174 & $51.2 \%$ & $0.12[-0.09,0.33]$ & \\
\hline Total $(95 \% \mathrm{Cl})$ & & & 305 & & & 308 & $100.0 \%$ & $-0.06[-0.41,0.30]$ & \\
\hline \multicolumn{9}{|c|}{ Heterogeneity: Tau $^{2}=0.05 ; \mathrm{Chi}^{2}=5.00, \mathrm{df}=1(P=0.03): \mathrm{P}^{2}=80 \%$} & 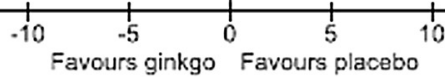 \\
\hline
\end{tabular}




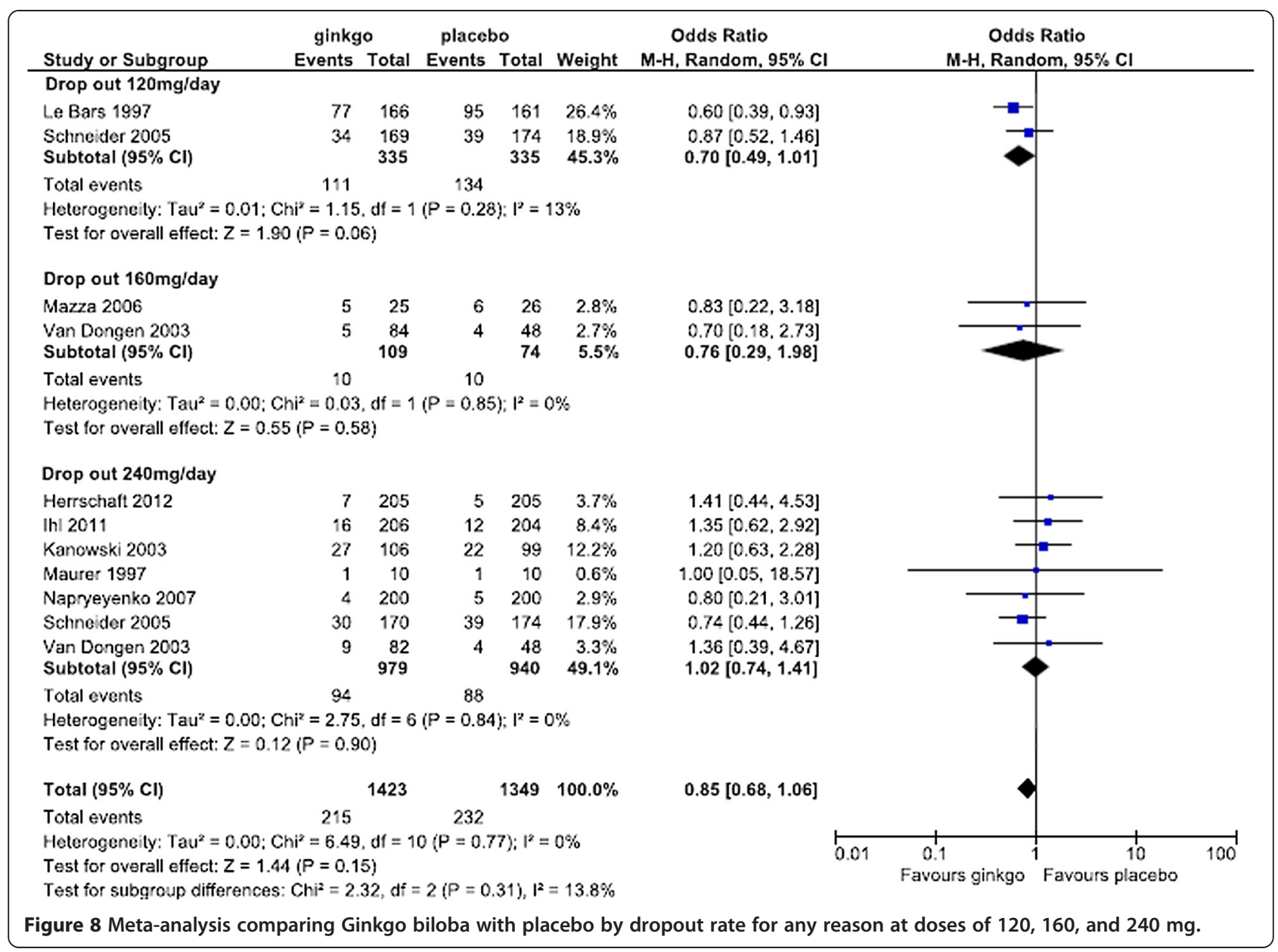

more studies, or in side effects experienced by $3-5 \%$ of patients from the beginning of treatment until 2 days after the end of the studies analyzed. In the meta-analysis for each side effect including headache, pulmonary infection, and elevation of blood pressure, no significant differences were found between Ginkgo biloba and placebo. On the other hand, the cumulative OR (95\% CI) for dizziness and tinnitus was $0.50(0.35,0.73)$ and $0.38(0.22,0.67)$, respectively, indicating a significantly lower incidence in the Ginkgo biloba compared with the placebo groups. Commission $\mathrm{E}$ of Germany also found that the treatment of dementia with Ginkgo biloba was not associated with the occurrence of dizziness and tinnitus. This study confirmed the preventive effect of Ginkgo biloba against dizziness and tinnitus. It is also known that many elderly people experience dizziness and tinnitus, and thus Ginkgo biloba preparations would be advantageous in preventing these side effects in those with dementia.

\begin{tabular}{|c|c|c|c|c|c|c|c|c|c|c|}
\hline Study or Subgroup & \multicolumn{2}{|c|}{ ginkgo } & \multicolumn{2}{|c|}{ placebo } & Weight & $\begin{array}{c}\text { Odds Ratio } \\
\text { M-H, Fixed, } 95 \% \mathrm{Cl}\end{array}$ & \multicolumn{4}{|c|}{$\begin{array}{c}\text { Odds Ratio } \\
\text { M-H, Fixed, } 95 \% \mathrm{Cl}\end{array}$} \\
\hline Herrschaft 2012 & 2 & 205 & 1 & 205 & $5.1 \%$ & $2.01[0.18,22.34]$ & & & & \\
\hline Ihl 2011 & 6 & 206 & 2 & 204 & $10.0 \%$ & $3.03[0.60,15.19]$ & & & & \\
\hline Le Bars 1997 (ALL) & 10 & 166 & 4 & 161 & $19.6 \%$ & $2.52[0.77,8.19]$ & & & 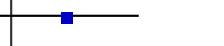 & \\
\hline Napryeyenko 2007 & 1 & 200 & 0 & 200 & $2.6 \%$ & $3.02[0.12,74.46]$ & & & & \\
\hline Schneider 2005 & 26 & 339 & 10 & 174 & $62.7 \%$ & $1.36[0.64,2.89]$ & & & & \\
\hline Total $(95 \% \mathrm{Cl})$ & & 1116 & & 944 & $100.0 \%$ & $1.83[1.04,3.22]$ & & & & \\
\hline Total events & 45 & & 17 & & & & & & & \\
\hline $\begin{array}{l}\text { Heterogeneity: } \mathrm{Chi}^{2}= \\
\text { Test for overall effect: }\end{array}$ & $\begin{array}{l}.34, \mathrm{df}= \\
Z=2.10\end{array}$ & $\begin{array}{l}4(P=0 \\
(P=0.04\end{array}$ & $\begin{array}{l}0.85) ; 1^{2}= \\
4)\end{array}$ & $=0 \%$ & & & 0.01 & $\begin{array}{c}0.1 \\
\text { Favours ginkgo }\end{array}$ & $\begin{array}{cc}1 & 10 \\
\text { Favours placebo }\end{array}$ & 100 \\
\hline
\end{tabular}




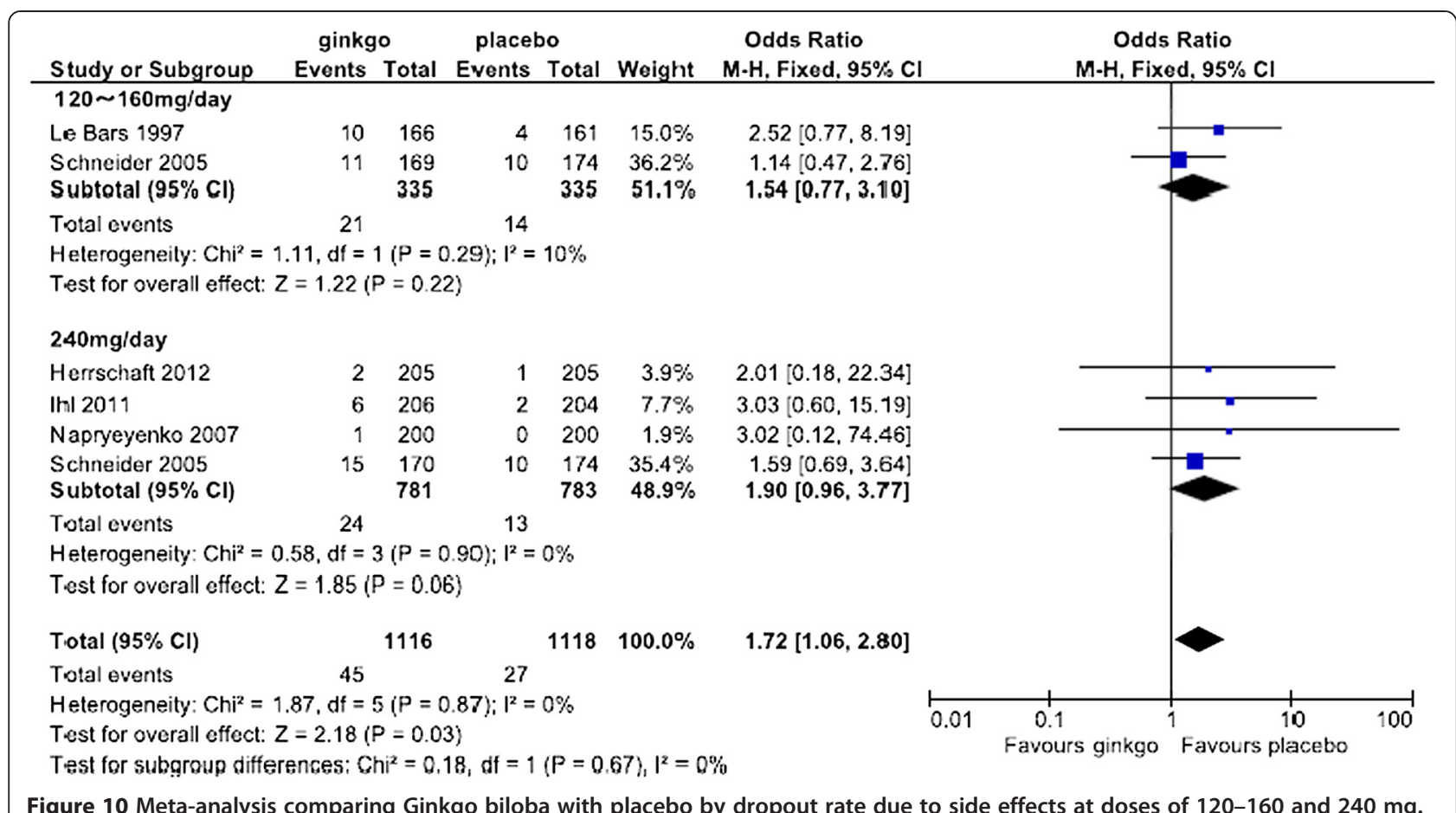

There were some limitations in this meta-analysis. Similar to the evaluation of other antidementia agents using the SMD at baseline and SKD and ADAS-Cog scores after treatment as clinical outcomes, it should be noted that the extent of treatment effect differs depending on baseline values. Although there was little difference in the baseline values in the studies included this metaanalysis, the study protocols, severity of disease, areas where the studies were performed, etc. differed. Therefore, we used the random-effect model in meta-analysis after determining the heterogeneity of the studies.

In summary, Ginkgo biloba appears more effective than placebo in the treatment of dementia at doses of more than $240 \mathrm{mg}$ daily administered for 22 weeks when using the SKT as a cognitive outcome measure, and safety did not differ markedly between them.

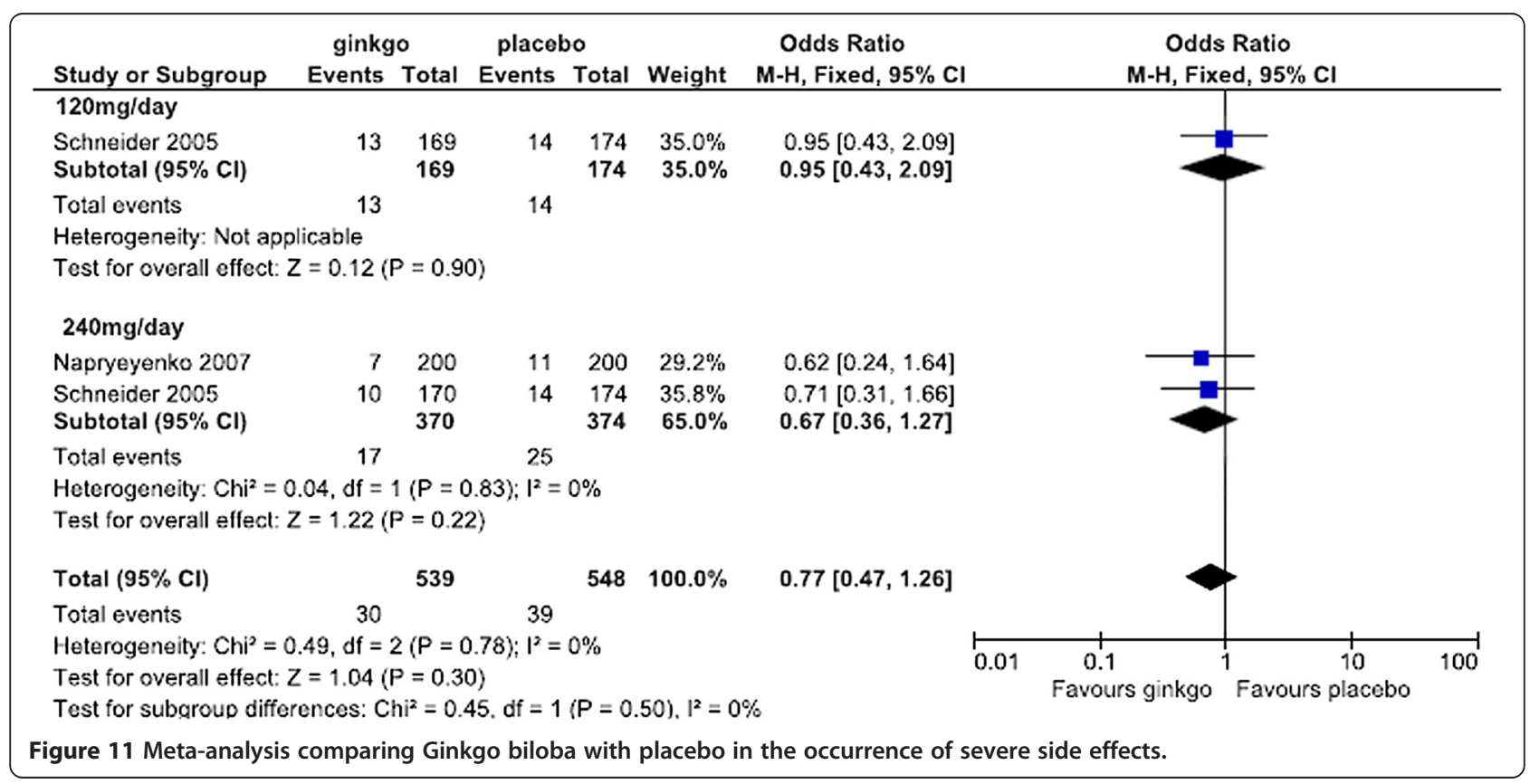




\begin{tabular}{|c|c|c|c|c|c|}
\hline $\begin{array}{l}\text { a Headache } \\
\text { Study or Subgroup }\end{array}$ & $\begin{array}{c}\text { ginkg } \\
\text { Events }\end{array}$ & $\begin{array}{l}10 \\
\text { Total }\end{array}$ & $\begin{array}{l}\text { placeb } \\
\text { Events }\end{array}$ & $\begin{array}{l}\text { bo } \\
\text { Total }\end{array}$ & Weight \\
\hline Herrschaft 2012 & 15 & 205 & 17 & 205 & $22.8 \%$ \\
\hline Inl 2011 & 43 & 206 & 38 & 204 & $29.6 \%$ \\
\hline Napryeyenko 2007 & 49 & 200 & 85 & 200 & $31.4 \%$ \\
\hline Schneider 2005 & 7 & 170 & 9 & 174 & $16.2 \%$ \\
\hline Total $(95 \% \mathrm{Cl})$ & & 781 & & 783 & $100.0 \%$ \\
\hline Total events & 114 & & 149 & & \\
\hline
\end{tabular}

Odds Ratio

Random, 95\% Cl

$0.87[0.42,1.80]$

$1.15[0.71,1.88]$

$0.44[0.29,0.67]$

$0.79[0.29,2.16]$

$0.75[0.44,1.28]$
Odds Ratio

M-H, Random, $95 \% \mathrm{CI}$

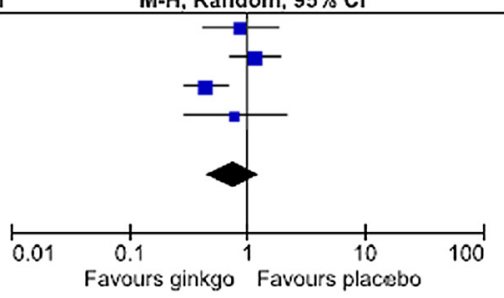

b Dizziness

ginkgo placebo Odds Ratio

Study or Subgroup Events Total Events Total Weight M-H, Fixed, $95 \% \mathrm{Cl}$

$\begin{array}{lllll}4 & 205 & 15 & 205 & 18.2 \%\end{array}$

$0.25[0.08,0.77]$

Ihl 2011

Napryeyenko 2007

$19 \quad 206$

$23 \quad 204 \quad 26.0 \%$

$0.80[0.42,1.52]$

Schneider 2005

12200

$\begin{array}{lll}36 & 200 \quad 42.0 \%\end{array}$

$0.29[0.15,0.58]$

$0.93[0.40,2.18]$

Total $(95 \% \mathrm{Cl})$

781

$174 \quad 13.8 \%$

Total events

46

$783 \quad 100.0 \%$

$0.50[0.35,0.73]$

Heterogeneity: $\mathrm{Chi}^{2}=7.96, \mathrm{df}=3(\mathrm{P}=0.05) ; \mathrm{I}^{2}=62 \%$

Test for overall effect: $Z=3.59(P=0.0003)$

M-H, Fixed, $95 \%$ Cl

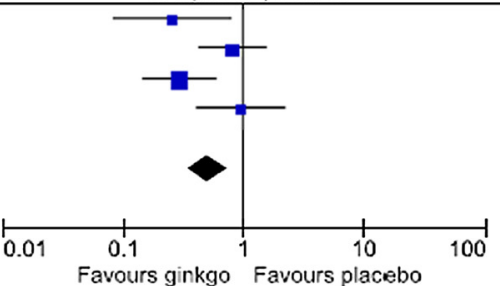

C Pulmonary infectious disease ginkgo placebo

Study or Subgroup Events Total Events Total Weight $\mathrm{M}-\mathrm{H}$, Fixed, $95 \% \mathrm{Cl}$

$\begin{array}{lllllll}\text { Herrschaft } 2012 & 8 & 205 & 6 & 205 & 11.7 \% & 1.35[0.46 .3 .95]\end{array}$

$\begin{array}{lllllll}\text { Ihl } 2011 & 27 & 206 & 20 & 204 & 35.4 \% & 1.39[0.75,2.56]\end{array}$

Napryeyenko 2007 $\quad 10 \quad 200 \quad 10 \quad 200 \quad 19.2 \% \quad 1.00[0.41,2.46]$

$\begin{array}{lllllll}\text { Schneider } 2005 & 11 & 170 & 18 & 174 & 33.7 \% & 0.60[0.27,1.31]\end{array}$

Total $(95 \% \mathrm{Cl})$

781

Total events $56 \quad 54$

Heterogeneity: $\mathrm{Chi}^{2}=2.98, \mathrm{df}=3(\mathrm{P}=0.39) ; \mathrm{I}^{2}=0 \%$

Test for overall effect: $Z=0.21(P=0.83)$

$1.04[0.71,1.54]$

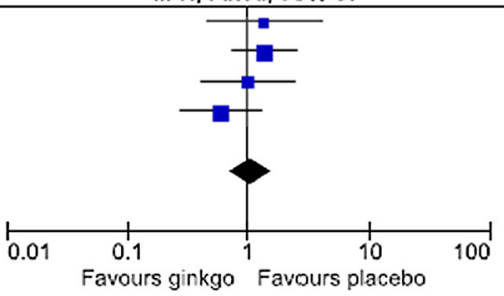

d Elevation of blood pressure

$\begin{array}{cccc}\text { ginkgo } & \text { placebo } & \text { Odds Ratio } \\ \text { Study or Subgroup } & \text { Events Total } & \text { Events } & \text { Total Weight } \\ \text { M-H, Fixed, } 95 \% \mathrm{Cl}\end{array}$

$\begin{array}{lrrrrrr}\text { Herrschaft 2012 } & 5 & 205 & 8 & 205 & 19.8 \% & 0.62[0.20,1.91] \\ \text { Ihl 2011 } & 22 & 206 & 21 & 204 & 47.8 \% & 1.04[0.55,1.96]\end{array}$

Napryeyenko 2007

4200

$13 \quad 200 \quad 32.3 \%$

$0.29[0.09,0.92]$

Total $(95 \% \mathrm{Cl})$

611

$609100.0 \%$

$0.72[0.44,1.16]$

Heterageneity: $\mathrm{Chi}^{2}=3.78, \mathrm{df}=2(\mathrm{P}=0.15) ; \mathrm{I}^{2}=47 \%$

Test for overall effect: $Z=1.36(P=0.17)$

Odds Ratio

$\mathrm{M}-\mathrm{H}$, Fixed, 95\% Cl

e Tinnitus

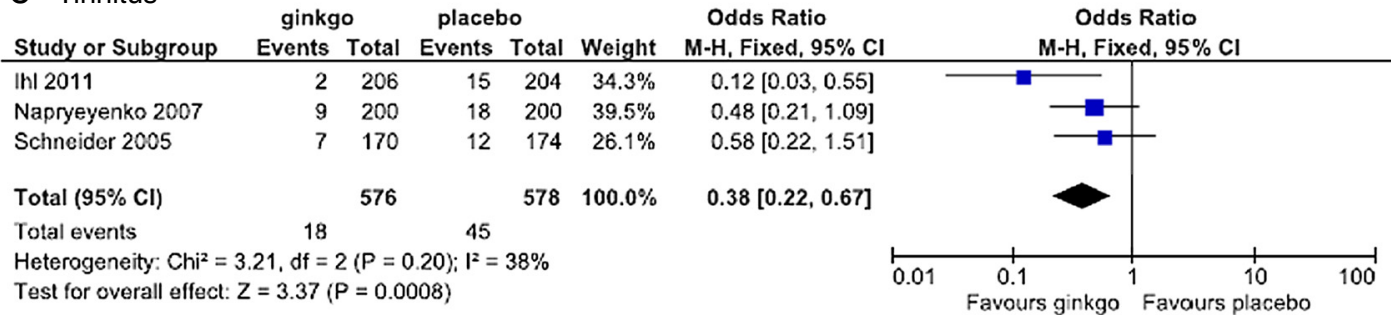

Figure 12 Meta-analysis comparing Ginkgo biloba with placebo in the occurrence of specific side effects. a: Headache; b: Dizziness;

c: Pulmonary infectious disease; d: Elevation of blood pressure; e: Tinnitus. 


\section{Conclusions}

Taking a 240-mg daily dose of Ginkgo biloba extract is effective in the treatment of dementia. Ginkgo biloba extract is therefore useful in improving the symptoms of dementia, as found in previous reports of meta-analyses. The evidence for efficacy and safety found in the present meta-analysis of the effects of Ginkgo biloba extract contributes to knowledge of the treatment of dementia.

\section{Competing interests}

The authors declare that they have no competing interests.

\section{Authors' contributions}

$\mathrm{MH}, \mathrm{YO}$, and $\mathrm{MS}$ carried out literature search, applied the inclusion criteria independently to the articles retrieved and evaluation of quality, data extraction from the articles, and meta-analysis. JM and MM helped to draft the manuscript. All authors read and approved the final manuscript.

\section{Acknowledgment}

This study was supported partially by the Ministry of Education, Culture, Sports, Science and Technology (MEXT)-Supported Program for the Strategic Research Foundation at Private Universities, 2011-2015.

\section{Author details}

'Division for Evaluation and Analysis of Drug Information, Faculty of Pharmacy, Keio University, 1-5-30 Shibakoen, Minato-ku, Tokyo 105-8512, Japan. ${ }^{2}$ Department of Hygienic Chemistry, Faculty of Pharmacy, Keio University, 1-5-30 Shibakoen, Minato-ku, Tokyo 105-8512, Japan.

Received: 9 September 2014 Accepted: 23 March 2015

\section{Published online: 10 April 2015}

\section{References}

1. Ginkgo biloba Leaf Extract. In: Blumenthal M, Busse W, Goldberg A, Gruenwald J, Hall T, Riggins C, Rister R., editors. The Complete German Commission E Monographs, Therapeutic Guide to Herbal Medicines: American Botanical Council; 1998. p.136-38.

2. Sasaki K, Matsuoka K. Pharmacology activity of a Ginkgo biloba extract. Chiba Inst Sci Bull. 2012;5:61-7 (In Japanese).

3. Hamann KF. Special Ginkgo extract in cases of vertigo: a systematic review of randomised, double-blind, placebo controlled clinical examinations. HNO. 2007:55:258-63.

4. Ernst E, Stevinson C. Ginkgo biloba for tinnitus: a review. Clin Otolaryngol Allied Sci. 1999;24(3):164-7.

5. Usai S, Grazzi L, Bussone G. Gingkolide B as migraine preventive treatment in young age: results at 1-year follow-up. Neurol Sci. 2011:32 Suppl 1:S197-9.

6. Sarris J, Panossian A, Schweitzer I, Stough C, Scholey A. Herbal medicine for depression, anxiety and insomnia: a review of psychopharmacology and clinical evidence. Eur Neuropsychopharmacol. 2011;21:841-60.

7. Weinmann S, Roll S, Schwarzbach C, Vauth C, Willich SN. Effects of Ginkgo biloba in dementia: systematic review and meta-analysis. BMC Geriatr. 2010;10:14.

8. Wang BS, Wang $H$, Song $Y Y$, Qi $H$, Rong ZX, Wang BS, et al. Effectiveness of standardized Ginkgo biloba extract on cognitive symptoms of dementia with a six-month treatment: a bivariate random effect meta-analysis. Pharmacopsychiatry. 2010;43:86-91.

9. Brondino N, De Silvestri A, Re S, Lanati N, Thiemann P, Verna A, et al. A systematic review and meta-analysis of Ginkgo biloba in neuropsychiatric disorders: From ancient tradition to modern-day medicine. Evid Based Complement Alternat Med. 2013;2013:915691. doi:10.1155/2013/915691. Epub 2013 May 28.

10. Jiang L, Su L, Cui H, Ren J, Li C. Ginkgo biloba extract for dementia: a systematic review. Shanghai Arch Psychiatr. 2013;25(1):10-21.

11. Birks J, Grimley EJ. Ginkgo biloba for cognitive impairment and dementia. Cochrane Database Syst Rev. 2009;1:CD003120.

12. Erzigkeit H. The SKT - a short cognitive performance test as an instrument for the assessment of clinical efficacy of cognitive enhancers. In: Bergner W, Reisberg B, editors. Diagnosis and treatment of senile dementia. Heidelberg: Springer-Verlag; 1989. p. 164-74.
13. Rosen WG, Mohs RC, Davis KL. A new rating scale for Alzheimer's disease. Am J Psychiatry. 1984;141:1356-64.

14. Jadad AR, Moore RA, Carroll D, Jenkinson C, Reynolds DJ, Gavaghan DJ, et al. Assessing the quality of reports of randomized clinical trials: is blinding necessary? Control Clin Trials. 1996;17:1-12.

15. Higgins JPT, Green S (eds). Cochrane Handbook for Systematic Reviews of Interventions, Version 5.1.0 (updated March 2011). The Cochrane Collaboration, 2011. Available from www.cochrane-handbook.org (accessed August 29, 2014).

16. Herrschaft H, Nacu A, Likhachev S, Sholomov I, Hoerr R, Schlaefke S. Ginkgo biloba extract EGb 761R in dementia with neuropsychiatric features: a randomised, placebo-controlled trial to confirm the efficacy and safety of a daily dose of $240 \mathrm{mg}$. J Psychiatr Res. 2012;46(6):716-23.

17. Ihl R, Bachinskaya N, Korczyn AD, Vakhapova V, Tribanek M, Hoerr R, et al. Efficacy and safety of a once-daily formulation of Ginkgo biloba extract EGb 761 in dementia with neuropsychiatric features: a randomized controlled trial. Int J Geriatr Psychiatry. 2011;26(11):1186-94.

18. Ihl R, Tribanek M, Bachinskaya N, for the GOTADAY Study Group. Efficacy and tolerability of a once daily formulation of Ginkgo biloba extract EGb $761^{\circledR}$ in Alzheimer's disease and vascular dementia: results from a randomised controlled trial. Pharmacopsychiatry. 2012;45(2):41-6.

19. Napryeyenko O, Borzenko I. GINDEM-NP Study Group. Ginkgo biloba special extract in dementia with neuropsychiatric features. A randomised, placebocontrolled, double-blind clinical trial. Arzneimittelforschung. 2007;57(1):4-11.

20. Napryeyenko O, Sonnik G, Tartakovsky. Efficacy and tolerability of Ginkgo biloba extract EGb 761 by type of dementia: analyses of a randomised controlled trial. J Neurol Sci. 2009;283(1-2):224-9.

21. Mazza M, Capuano A, Bria P, Mazza S. Ginkgo biloba and donepezil: a comparison in the treatment of Alzheimer's dementia in a randomized placebo-controlled double-blind study. Eur J Neurol. 2006;13(9):981-5.

22. Kanowski S, Hoerr R. Ginkgo biloba extract EGb 761 in dementia: intent-to-treat analyses of a 24-week, multi-center, double-blind, placebo-controlled, randomized trial. Pharmacopsychiatry. 2003;36(6):297-303.

23. van Dongen $M$, van Rossum E, Kessels A, Sielhorst H, Knipschild P. Ginkgo for elderly people with dementia and age-associated memory impairment: a randomized clinical trial. J Clin Epidemiol. 2003;56(4):367-76.

24. Maurer K, Ihl R, Dierks T, Frolich L. Clinical efficacy of Ginkgo biloba special extract EGb 761 in dementia of the Alzheimer type. J Psychiatr Res. 1997;31(6):645-55.

25. Schneider LS, DeKosky ST, Farlow MR, Tariot PN, Hoerr R, Kieser M. A randomized, double-blind, placebo-controlled trial of two doses of Ginkgo biloba extract in dementia of the Alzheimer's type. Curr Alzheimer Res. 2005;2(5):541-51.

26. Le Bars PL, Katz MM, Berman N, Itil TM, Freedman AM, Schatzberg AF. A placebo-controlled, double-blind, randomized trial of an extract of Ginkgo biloba for dementia. North American EGb Study Group JAMA. 1997;278(16):1327-32.

27. Le Bars PL, Kieser M, Itil KZ. A 26-week analysis of a double-blind, placebocontrolled trial of the ginkgo biloba extract EGb 761 in dementia. Dement Geriatr Cogn Disord. 2000;11(4):230-7.

28. Le Bars PL, Velasco FM, Ferguson JM, Dessain EC, Kieser M, Hoerr R. Influence of the severity of cognitive impairment on the effect of the Ginkgo biloba extract EGb 761 in Alzheimer's disease. Neuropsychobiology. 2002;45(1):19-26.

29. Kim YS, Nibbelink DW, Overall JE. Factor structure and scoring of the SKT test battery. J Clin Psychol. 1993;49(1):61-71.

30. Itil TM, Eralp E, Tsambis $E_{1}$ Itil KZ, Stein U. Central nervous system effects of Ginkgo biloba, a plant extract. Am J Ther. 1996;3(1):63-73. 